\title{
Evaluation of Tomato (Solanum lycopersicon L.) Hybrids for Fruit Yield Characters in Hill Region of Uttarakhand, India
}

\author{
Shivani Dhyani*, A.C. Misra, Vivek Panday and Paramjeet Sajwan \\ Department of Vegetable Science, College of Forestry, Ranichauri Campus-249199, VCSG \\ Uttarakhand, University Horticulture and Forestry, Bharsar, Uttarakhand, India \\ *Corresponding author
}

\section{A B S T R A C T}

\begin{tabular}{|l|}
\hline Ke y w or d s \\
$\begin{array}{l}\text { Tomato, Solanum } \\
\text { lycopersicon L., } \\
\text { Hybrid. }\end{array}$ \\
\hline Article Info \\
\hline $\begin{array}{l}\text { Accepted: } \\
\text { 19 July } 2017 \\
\text { Available Online: } \\
\text { 10 September } 2017\end{array}$ \\
\hline
\end{tabular}

Tomato is a premier vegetable crop of round the year and one of the prominent ecoindustrial crops of India generating sizeable employment. The present study which consist $22 \mathrm{~F}_{1}$ including commercial 6 hybrids of tomato. The experiment was laid out in Randomized Block Design (RBD) with three replications during summer- rainy season, 2014 at Vegetable Block of VCSG Uttarakhand University of Horticulture and Forestry, Ranichauri, Tehri-Garhwal. Analysis of variance (ANOVA) revealed significant differences among the hybrids for all the characters. The hybrid viz., Utkal Urwasi $\mathrm{X}$ Gujrat Tomato-3 proved the best with respect to fruit yield $(6935.08 \mathrm{~g})$ whereas, Utkal Urwasi X Palam Pink was promising for number of fruit per plant (79.82), number of flower cluster per plant (14.13), number of flower per cluster (8.0) and fruit set percentage (85.71\%). The hybrid Marglobe X Pusa Sadabhar was the best for earlist picking (43.0 DAT) and highest fruit weight (106.74 g).

\section{Introduction}

Tomato (Solanum lycopersicon L.) is one of the most popular and widely grown vegetable in the world. It belongs to the family Solanaceae. It is originated in a wild from in the Peru-Ecuador Bolivia region of the Andes in South America. Tomato was first introduced in Europe in the middle of the sixteenth century and in India it is introduced during seventeenth century probably by Portuguese (Kalloo, 1991). It is a major source of vitamins and minerals particularly vitamin C (31.0 mg), vitamin A (321 IU), protein $(1.98 \mathrm{~g})$, moisture $(93.1 \mathrm{~g})$, minerals $(0.6 \mathrm{~g})$, fibre $(0.7 \mathrm{~g})$, sulphur (24 mg), chlorine (38 mg) and calcium (20 mg) on per $100 \mathrm{~g}$ fresh weight basis.
The pulp and juice are digestible mild aperients and blood purifier. It has antiseptic properties against intestinal infections.

India is the second largest tomato producing country in the world after China and contributes about $11.5 \%$ to the global tomato production. As per NHB report 2015-16, in India, tomato is grown in an area of $0.767 \mathrm{~m}$ ha with annual production of $16.385 \mathrm{~m}$ tonnes and productivity of $21.36 \mathrm{t} / \mathrm{ha}$.

Andhra Pradesh, Karnataka, Madhya Pradesh, Telangana and Odisha are the five major tomato growing states of the country (Anonymous, 2015). 
Genetic variability is defined as "The occurrence of a high degree of variation differences among individuals due to differences in their genetic composition and of the environment in which they are raised" (Falconer and Mackay 1996). The basic requirement for genetic improvement of a crop is to utilize the available or created genetic variability. The genus Lycopersicon has two subgenera, Eulycopersicon, red fruited and self -compatible, and Eriopersicon, green-fruited and selfincompatible. In tomatoes three types of growth habit are found. In Indeterminate types of tomato the terminal bud ends in leafy bud and there is a continuous vegetative growth. The determinate types of tomato have terminal bud ending in a floral bud and further vegetative growth is checked and the semi-determinate types are in between determinate and indeterminate and have varing number of nodes between two consecutive inflorescences. Tomato flower is normally perfect. There are four to eight flowers in each compound inflorescence. There is a light protective anther cone surrounding the stigma leading to selfpollination. In tomato, anthesis and dehiscence occur between 7.00-8.00 am and 9.00-11.00 am respectively, Pollen fertility is maximum on the day of anthesis and stigma is fully receptivity at $16 \mathrm{hrs}$ before anthesis to the day of anthesis (Sindhu et al., 1980).

Wild tomatoes have a large genetic diversity, especially within the self- incompatible species like $L$. chilense and $L$. peruvianum (Rick, 1998). The genetic variation present in the wild species has been investigated intensively for the specific traits and is being exploited in tomato breeding (Larry and Joanne, 2007). Advance in tomato breeding for resistant are due to mostly the incorporation of major resistant genes identified from the Lycopersicon species (Rajdan and Mattoo, 2006). Resistance to most important insect in tomatoes has been reported in wild species, particularly $L$. hirsutum that possesses resistant to at least eighteen pest species (Momotaz et al., 2005) and L. pennellii (Muigai et al., 2002).

Utilization of desirable genes conferring resistance to biotic and abiotic stress available in different wild and cultivated gene pool could be possible through hybrid breeding programmes. In addition to resistance characteristics quantum rise in fruit yield has also been taken place in tomato in last two decades. The basic force behind such a miracle achievement in relation to production and productivity of this crop was development of $F_{1}$ hybrids suitable for different agro-climatic conditions. The tomato hybrids got quick popularity due to occurrence heterosis for fruit yield characteristics.

The agro-climatic conditions of Uttarakhand hills are known for its variability, uncertainty and extremity. This region is 'hot spot' of almost all the biotic and abiotic stresses, like early or late onset of Monsoon, flush rains, erratic and unevenly distributed rainfall, leaf blight, bacterial wilt, fruit rot, fruit borer etc. With these colleges cultivation of conventional varieties of tomato prone to be uneconomical enterprise. Hybrid have been found to be more suitable for ensured yield under such extreme agro-ecological situation of hills.

With the view to combat these problems, evaluation of hybrid in rain fed temperate hills of Uttarakhand is indispensable for boosting the production of tomatoes in the state and as such, an experiment has been planned to evaluate the available hybrids of tomato with objectives of to evaluate the commercial as well as newly developed hybrids for plant growth and fruit yield characters. 


\section{Materials and Methods}

The material for present study consisted of 22 hybrids of tomato. The experiment was evaluated at Vegetable Research Block, VCSG Uttarakhand University of Horticulture and Forestry, Ranichauri Campus, Tehri Garhwal in the month of summer-rainy season March-August in 2014. Tehri Garhwal situated at $2000 \mathrm{~m}$ altitude, $78^{\circ} 24 \mathrm{E}$ longitude and $30^{\circ} 18^{\prime} \mathrm{N}$ latitude receiving average annual rainfall of $1230 \mathrm{~mm}$ with maximum and minimum temperature of $26.6^{\circ} \mathrm{C}$ and $9.9^{\circ} \mathrm{C}$, respectively. The Ranichauri Campus experiences humid and temperate type of climate with chilled winters. During cropping season of tomato the mean maximum temperature varied from $19.6^{\circ} \mathrm{C}$ to $26.6^{\circ} \mathrm{C}$ and mean minimum temperature from $9.9^{\circ} \mathrm{C}$ to $16.9^{\circ} \mathrm{C}$. The average annual rainfall 1278.4 $\mathrm{mm}$ was experienced. Major portion of annual rainfall (about $61 \%$ ) occurs during monsoon. Winter rains and snowfall occur during December-February and hailstorms are frequent from mid-April to May. The experiment was laid out in a Randomized Block Design (R.B.D.) with 3 replications and 22 number of treatments. The 30 days old seedlings transplanted into the field keeping the row-to-row and plant-to-plant distances of 60 and $45 \mathrm{~cm}$, respectively. Observation were taken days to first flowering, internodal length $(\mathrm{cm})$, plant height at first flowering $(\mathrm{cm})$, plant height at first picking $(\mathrm{cm})$, number of primary branches, number of secondary branches, leaf area $\left(\mathrm{cm}^{2}\right)$, node number of first flowering, number of flower cluster per plant, number of flower per cluster, fruit set percentage, days to first picking, fruit length $(\mathrm{cm})$, fruit diameter $(\mathrm{cm})$, fruit pericarp thickness $(\mathrm{mm})$, number of fruit locules, fruit weight $(\mathrm{g})$, fruit volume $\left(\mathrm{cm}^{3}\right)$, specific gravity of fruit $\left(\mathrm{g} / \mathrm{cm}^{3}\right)$, number of fruit per plant and fruit yield per plant (g) were recorded on five randomly selected plant basis.

\section{Results and Discussion}

\section{Days to first flowering}

The mean value of hybrids for this trait depicted that Omnia was the earliest to exhibit first flowering (26.33 DAT) followed by Himshikhar (27 DAT), Gujrat Tomato-3 x Pusa Sheetal (28.33 DAT), NDT-7 x S-2 (28.33 DAT), Abhilash (28.33 DAT) and VS2853 (28.66 DAT) which were statistically at par with each other. The maximum number of days to first flowering was found in $\mathrm{CO}-3 \mathrm{x}$ Pusa Sadabahar (41.66 DAT). The population mean was found to be 31.71 DAT. Earlier flowering hybrids could be used for production of early fruits for higher remuneration particularly in hills where offseason production enable higher profit. Variability in days to first flowering has also been reported by Ali et al., (2012) from 42.00 to 56.00 DAS, Shankar et al., (2013) from 28.00 to 37.00 DAT, Singh et al., (2013) from 49.88 to 53.92 DAS and Said et al., (2014) from 29 to 41 DAS in tomato (Table 1).

\section{Internodal length $(\mathrm{cm})$}

Significant difference for internodal length among the hybrids was noted (Table 1). The maximum internodal length was recorded in Palam Pink x Pusa Sadabahar $(8.50 \mathrm{~cm})$ followed by check Pusa Hybrid-1 $(8.35 \mathrm{~cm})$, CO-3 x Utkal Urwasi $(8.25 \mathrm{~cm})$ and Punjab Chuhara x Pusa Uphar $(8.25 \mathrm{~cm})$ with at par values. Minimum internodal length was recorded in S-2 x Utkal Uphar and Utkal Kumari x Utkal Uphar $(4.25 \mathrm{~cm})$. While the population mean was found to be $6.45 \mathrm{~cm}$. Internodal length is a character which decides growth habit of the plants. For example, indeterminate types with higher internodal length grow tall utilizing vertical space and give more fruit yield for longer time. Similar results on intermodal length have also been reported by Chaurasia et al., (2001) from 6.5 
$\mathrm{cm}$ to $7.9 \mathrm{~cm}$ in two hybrids (BSS-40 and ARTH-4) of tomato.

\section{Number of flower clusters per plant}

The number of flower clusters per plant is an important yield determining trait. Higher number of flower clusters may lead to greater number of fruits per plant in favorable conditions. The data on number of flower clusters per plant indicated that the mean value for this trait ranged from 7.33 to 14.13 . The hybrids differed significantly for number of flower clusters per plant. Among all the hybrids, maximum number of flower clusters per plant was observed in Utkal Urwasi $\mathrm{x}$ Palam Pink (14.13) followed by statistically at par values in NDT-7 x S-2 (13.83) and check Pusa Hybrid-1 (13.53). Whereas, minimum number of flower clusters per plant was observed in Gujart Tomato-3 x Swarna Lalima (7.33). The population mean for this trait was 11.48. The results of present investigation could also be compared with findings of Sekhar et al., (2009) (19.47 to 36.27), Alam et al., (2010) from (5.7 to 7.5) and Singh et al., (2014) (6.00 to 8.33) in tomato hybrids (Table 1).

\section{Number of flowers per cluster}

Perusal of the data on number of flowers per cluster indicated that maximum number was recorded in Utkal Urwasi x Palam Pink (8.00) followed by Palam Pink x Pusa Sadabahar (7.93), S-2 x Utkal Uphar (7.70), Utkal Urwasi x Gujrat Tomato-3 (7.63), Pusa Uphar $x$ Utkal Kumari (7.63) and CO-3 x Pusa Sadabahar (7.36) which were statistically at par. Lowest number of flowers per cluster was noted in NDT-7 x S-2 (5.46). The general mean of the population for this trait was 6.72. More number of flowers per cluster might be associated with more number of fruit setting in a particular hybrid under congenial agroclimatic conditions. Similar results on variation in number of flowers per clusters have also been reported by Shankar et al., (2013) from 4.53 to 6.37, Cheema et al., (2013) from 4.00 to 9.00 and Sekhar et al., (2009) from 4.87 to 7.20 in tomato hybrids and open pollinated varieties (Table 1).

\section{Fruit set percentage}

Significant differences were observed among the hybrids with respect to fruit set percentage. It varied between $33.33 \%$ and $85.71 \%$. Utkal Urwasi x Palam Pink had greater potentiality to exhibit maximum fruit setting $(85.71 \%)$ which was significantly higher than all the other hybrids tested in present investigation. This was a consequence of production of more number of flower cluster per plant and less effect of adverse climatic conditions like rainfall and wind velocity during crop growth and development. The other hybrids with higher fruit set percentage were Marglobe $x$ Palam Pink (75.0\%) and Palam Pink x Pusa Sadabahar (75.0\%). From the results it is evident that the hybrids exhibiting higher fruit setting percentage had one parent Palam Pink in common. Minimum value for fruit set percentage was observed in Himsona (33.33\%). The population mean was $66.71 \%$. Fruit set percentage in tomato is one of the important parameter for the rainy season tomato yield in hills, which is also a measurement of a particular hybrid/variety towards tolerance to low temperature and high rainfall. In the most of cases, fruit setting ability of a particular hybrid/variety determines ultimate fruit yield in tomato (Alam et al., 2010 and Singh et al., 2014). While studying the performance of tomato hybrids, Alam et al., (2010) also reported a range of fruit set percentage from $32.96 \%$ to $52.86 \%$, Similarly Singh et al., (2014) reported highest fruit set in cultivar Laxmi $(80.50 \%)$ and lowest in PS-61 (50.65\%) (Table 1). 


\section{Plant height at first flowering (cm)}

The data pertaining to plant height at first flowering has been given in (Table 1). Maximum plant height was observed in S-2 $\mathrm{x}$ Utkal Uphar $(20.60 \mathrm{~cm})$ which was followed by Gujrat Tomato-3 x Pusa Sheetal (20.16 $\mathrm{cm})$, Marglobe x Pusa Sadabahar $(19.83 \mathrm{~cm})$, NDT-7 x S-2 (19.60 cm), Azad T-6 x Punjab Chuhara $(19.30 \mathrm{~cm})$, CO-3 x Utkal Urwasi $(18.60 \mathrm{~cm})$, Himshikhar $(18.53 \mathrm{~cm})$, Himsona $(18.53 \mathrm{~cm})$, Azad T-6 x NDT-7 $(18.46 \mathrm{~cm})$, CO-3 x Pusa Sadabahar $(18.33 \mathrm{~cm})$, Palam Pink x Pusa Sadabahar $(18.33 \mathrm{~cm})$ and Gujrat Tomato-3 x Swarna Lalima $(17.46 \mathrm{~cm})$ with at par values. The lowest value of plant height was found in Utkal Kumari x Utkal Uphar $(13.06 \mathrm{~cm})$. The mean value of population was $17.82 \mathrm{~cm}$.

\section{Plant height at first picking (cm)}

The data on plant height at first picking has been depicted in (Table 1). Perusal of the data revealed that the variability in plant height at first picking ranged from $(18.50 \mathrm{~cm})$ to $(72.26$ $\mathrm{cm}$ ) and the maximum and significantly higher plant height was observed in CO-3 x Pusa Sadabahar $(72.26 \mathrm{~cm})$ followed by CO-3 $x$ Utkal Urwasi $(68.16 \mathrm{~cm})$, check Pusa Hybrid-1 $(68.13 \mathrm{~cm})$, Azad T-6 x Punjab Chuhara $(67.53 \mathrm{~cm})$ and Abhilash $(65.20 \mathrm{~cm})$. Minimum plant height was observed in Utkal Urwasi x Gujrat tomato-3 $(18.50 \mathrm{~cm})$. The population mean for this trait was found to be $(42.96 \mathrm{~cm})$. The plant height at flowering and fruiting generally indicates the growth habit of the hybrids and according the potentiality of the cultivar/ hybrid could be guessed. Variable plant height of different hybrids was mainly due to differences in their genetic make-up. Variability in plant height at flowering and fruiting has also been obtained by Alam et al., (2010) from $115.9 \mathrm{~cm}$ to 139.5 $\mathrm{cm}$, Ali et al., (2012) from $56.82 \mathrm{~cm}$ to 72.00 $\mathrm{cm}$, Shankar et al., (2013) from $48.33 \mathrm{~cm}$ to $153.63 \mathrm{~cm}$, Sharma et al., (2013) from 57.9 cm to $162.39 \mathrm{~cm}$, Singh et al., (2013) 53.73 $\mathrm{cm}$ to $83.67 \mathrm{~cm}$ and Saleem et al., (2013) from $76 \mathrm{~cm}$ to $126 \mathrm{~cm}$ in hybrid tomatoes.

\section{Number of primary branches}

There was significant variation in number of primary branches across the hybrids (Table 2 ). The mean value for this trait exhibited a range of number of primary branches from 4.80 to 8.00 . Maximum number of primary branches was found in S-2 x Utkal Uphar (8.00) followed by Azad T-6 x NDT-7 (7.93), Gujrat Tomato-3 x Swarna Lalima (7.76), check Pusa Hybrid-1 (7.46), Abhilash (7.40) and Gujrat Tomato-3 x Pusa Sheetal (7.13) which were statistically at par with each other. Minimum value was found in the Marglobe x Pusa Sadabahar (4.80). The population mean for number of primary branches was observed to be 6.595 .

\section{Number of secondary branches}

Different hybrids exhibited significant differences in regard to number of secondary branches. The mean value for this trait exhibited a range of 25.46 to 39.23. Maximum number of secondary branches was found in Gujrat Tomato-3 x Swarna Lalima (39.23) which was significantly higher than that in other hybrids. Minimum value of number of secondary branches was found in the VS-2853 (25.46). The population mean for this trait was 32.28 .

Variability in number of branches in tomato hybrids have also been reported by Alam et al., (2010) from 4.3 to 6.7, Singh et al., (2013) from 15.29 to 24.2 and Shankar et al., (2013) from 5.33 to 10.60 (Table 2).

\section{Leaf area}

Leaf area represents photosynthetic plant surface area the product of which is stored in fruits. More leaf area means more 
carbohydrate synthesis likely to occur for transformation in the fruits. Therefore, leaf area could also be a yield indicator of the hybrids. The analyzed data on leaf area is presented in (Table 2). Significantly higher value of leaf area was observed in Himsona $\left(26.83 \mathrm{~cm}^{2}\right)$. The other hybrids with higher leaf area were S-2 x Utkal Uphar $\left(22.76 \mathrm{~cm}^{2}\right)$, Utkal Urwasi x Palam Pink $\left(22.50 \mathrm{~cm}^{2}\right)$ and
Utkal Kumari x Utkal Uphar $\left(21.13 \mathrm{~cm}^{2}\right)$. While, minimum value of leaf area was exhibited by check Pusa Hybrid-1 (13.30 $\mathrm{cm}^{2}$ ). The population mean for this character was $19.09 \mathrm{~cm}^{2}$. Variability in leaf area of tomato hybrids has also been reported by Ahmad et al., (2007) from 8.0 to $10.0 \mathrm{~cm}^{2}$, Babu et al., (2012) from 10.2 to $18.24 \mathrm{~cm}^{2}$ and Ali et al., (2012) from 16.20 to $17.21 \mathrm{~cm}^{2}$.

Table.1

\begin{tabular}{|c|c|c|c|c|c|c|c|}
\hline Hybrids & $\begin{array}{l}\text { Days } \\
\text { to first } \\
\text { flower } \\
\text {-ing }\end{array}$ & $\begin{array}{l}\text { Internodal } \\
\text { length }(\mathrm{cm})\end{array}$ & $\begin{array}{l}\text { Number of } \\
\text { flower per } \\
\text { cluster }\end{array}$ & $\begin{array}{l}\text { Number of } \\
\text { flower cluster } \\
\text { Per plant }\end{array}$ & $\begin{array}{l}\text { Fruit set } \\
\text { Perce- } \\
\text { ntage }\end{array}$ & $\begin{array}{l}\text { Plant } \\
\text { height at } \\
\text { first } \\
\text { flowering } \\
\text { (cm) }\end{array}$ & $\begin{array}{l}\text { Plant } \\
\text { height at } \\
\text { first } \\
\text { picking } \\
\text { (cm) }\end{array}$ \\
\hline Gujrat Tomato-3 x Swarna Lalima & 31.00 & 5.25 & 6.69 & 7.33 & 66.66 & 17.46 & 18.90 \\
\hline Azad T-6 x Punjab Chuhara & 34.00 & 6.50 & 6.43 & 8.26 & 66.66 & 19.30 & 67.53 \\
\hline CO-3 X Pusa Sadabahar & 41.66 & 5.50 & 7.36 & 8.50 & 71.42 & 18.33 & 72.26 \\
\hline Azad T-6 X NDT-7 & 35.33 & 5.25 & 6.96 & 9.30 & 71.46 & 18.46 & 26.20 \\
\hline Utkal Kumari x Utkal Uphar & 32.00 & 4.25 & 7.00 & 9.50 & 71.48 & 13.06 & 26.20 \\
\hline Pusa Uphar X Utkal Kumari & 32.66 & 5.75 & 7.63 & 8.56 & 71.50 & 17.00 & 47.93 \\
\hline Marglobe x Palam Pink & 33.00 & 7.25 & 5.69 & 10.20 & 75.00 & 17.26 & 43.43 \\
\hline Palam Pink x Pusa Sadabahar & 33.00 & 8.50 & 7.93 & 11.36 & 75.00 & 18.33 & 44.10 \\
\hline Marglobe x Pusa Sadabahar & 29.00 & 7.75 & 6.73 & 11.90 & 66.66 & 19.83 & 35.20 \\
\hline CO-3 X Utkal Urwasi & 29.33 & 8.25 & 5.83 & 13.36 & 60.00 & 18.60 & 68.16 \\
\hline Utkal Urwasi x Gujrat Tomato-3 & 36.66 & 5.50 & 7.63 & 12.43 & 71.52 & 17.13 & 18.50 \\
\hline S-2 X Utkal Uphar & 33.00 & 4.25 & 7.70 & 11.06 & 71.54 & 20.60 & 37.50 \\
\hline Utkal Urwasi x Palam Pink & 32.00 & 5.75 & 8.00 & 14.13 & 85.71 & 15.00 & 37.06 \\
\hline Gujrat Tomato-3 x Pusa Sheetal & 28.33 & 6.25 & 6.00 & 12.76 & 66.66 & 20.16 & 33.26 \\
\hline NDT-7 x S-2 & 28.33 & 7.50 & 5.46 & 13.83 & 60.00 & 19.60 & 35.93 \\
\hline Punjab Chuhara x Pusa Uphar & 33.00 & 8.25 & 6.46 & 12.43 & 66.66 & 16.86 & 33.06 \\
\hline Abhilash & 28.33 & 6.75 & 6.16 & 12.63 & 60.00 & 16.46 & 65.20 \\
\hline Pusa Hybrid-1 & 32.00 & 8.35 & 6.16 & 13.53 & 60.00 & 17.26 & 68.13 \\
\hline Himshikhar & 27.00 & 6.25 & 6.20 & 13.30 & 60.00 & 18.53 & 57.03 \\
\hline Himsona & 33.00 & 7.75 & 6.26 & 12.63 & 33.33 & 18.53 & 43.20 \\
\hline VS- 2853 & 28.66 & 6.50 & 6.96 & 13.30 & 71.56 & 17.33 & 33.06 \\
\hline Omnia & 26.33 & 7.75 & 6.56 & 12.26 & 60.00 & 17.06 & 33.16 \\
\hline 'F'test & $* *$ & $* *$ & $* *$ & $* *$ & $* *$ & $*$ & $* *$ \\
\hline GM & 31.712 & 6.455 & 6.722 & 11.483 & 66.714 & 17.828 & 42.962 \\
\hline SEM & 0.772 & 0.954 & 0.244 & 0.200 & 0.290 & 1.109 & 1.7554 \\
\hline $\mathrm{CD}$ at $5 \%$ & 2.205 & 0.27 & 0.696 & 0.571 & 0.828 & 3.165 & 5.010 \\
\hline $\mathrm{CV} \%$ & 4.22 & 2.57 & 6.288 & 3.020 & 0.753 & 10.77 & 7.077 \\
\hline
\end{tabular}


Table.2

\begin{tabular}{|c|c|c|c|c|c|c|c|}
\hline Hybrids & $\begin{array}{l}\text { Number of } \\
\text { primary } \\
\text { branches }\end{array}$ & $\begin{array}{l}\text { Number of } \\
\text { seconday } \\
\text { branches }\end{array}$ & $\begin{array}{l}\text { Leaf } \\
\operatorname{area}\left(\mathrm{cm}^{2}\right)\end{array}$ & $\begin{array}{l}\text { Days to first } \\
\text { picking }\end{array}$ & $\begin{array}{l}\text { Node number } \\
\text { of first } \\
\text { flowering }\end{array}$ & $\begin{array}{l}\text { Polar fruit } \\
\text { diameter }(\mathrm{cm})\end{array}$ & $\begin{array}{l}\text { Radial Fruit } \\
\text { diameter }(\mathrm{cm})\end{array}$ \\
\hline Gujrat Tomato-3 x Swarna Lalima & 7.76 & 39.23 & 15.76 & 46.66 & 5.50 & 3.50 & 10.50 \\
\hline Azad T-6 x Punjab Chuhara & 4.83 & 37.66 & 18.10 & 47.66 & 6.66 & 6.83 & 13.13 \\
\hline CO-3 X Pusa Sadabahar & 6.80 & 36.71 & 20.83 & 60.00 & 11.03 & 8.00 & 15.16 \\
\hline Azad T-6 X NDT-7 & 7.93 & 36.10 & 16.96 & 50.66 & 5.50 & 7.86 & 15.13 \\
\hline Utkal Kumari x Utkal Uphar & 5.96 & 35.93 & 21.13 & 48.33 & 4.33 & 6.66 & 13.53 \\
\hline Pusa Uphar X Utkal Kumari & 6.26 & 34.16 & 14.76 & 46.33 & 4.90 & 8.23 & 11.73 \\
\hline Marglobe x Palam Pink & 6.06 & 34.13 & 22.13 & 48.33 & 6.56 & 7.43 & 14.66 \\
\hline Palam Pink x Pusa Sadabahar & 7.10 & 33.23 & 17.23 & 52.33 & 6.03 & 7.90 & 17.13 \\
\hline Marglobe x Pusa Sadabahar & 4.80 & 28.90 & 18.73 & 43.00 & 6.20 & 8.26 & 16.80 \\
\hline CO-3 X Utkal Urwasi & 6.63 & 26.26 & 18.73 & 47.00 & 7.06 & 8.43 & 16.86 \\
\hline Utkal Urwasi x Gujrat Tomato-3 & 6.76 & 30.33 & 18.70 & 52.31 & 5.50 & 8.30 & 15.70 \\
\hline S-2 X Utkal Uphar & 8.00 & 31.96 & 22.76 & 47.00 & 6.90 & 8.46 & 14.73 \\
\hline Utkal Urwasi x Palam Pink & 6.86 & 29.26 & 22.50 & 46.00 & 7.06 & 8.70 & 16.60 \\
\hline Gujrat Tomato-3 x Pusa Sheetal & 7.13 & 29.70 & 18.03 & 44.00 & 5.20 & 8.53 & 16.46 \\
\hline NDT-7 x S-2 & 6.20 & 33.10 & 18.93 & 47.66 & 6.16 & 11.33 & 14.73 \\
\hline Punjab Chuhara x Pusa Uphar & 5.93 & 32.23 & 19.20 & 52.66 & 6.56 & 7.76 & 14.53 \\
\hline Abhilash & 7.40 & 31.83 & 19.16 & 44.32 & 5.50 & 7.50 & 15.70 \\
\hline Pusa Hybrid-1 & 7.46 & 30.56 & 13.30 & 48.00 & 5.00 & 8.50 & 15.56 \\
\hline Himshikhar & 7.03 & 27.93 & 16.06 & 44.00 & 6.56 & 9.26 & 16.60 \\
\hline Himsona & 5.86 & 32.80 & 26.83 & 47.00 & 6.86 & 8.49 & 14.53 \\
\hline VS- 2853 & 6.00 & 25.46 & 19.56 & 45.33 & 6.06 & 8.09 & 15.23 \\
\hline Omnia & 6.20 & 32.76 & 20.63 & 46.66 & 6.06 & 10.16 & 20.86 \\
\hline 'F'test & $* *$ & $* *$ & ** & $* *$ & $* *$ & $* *$ & $* *$ \\
\hline GM & 6.595 & 32.287 & 19.095 & 47.969 & 6.3575 & 8.102 & 15.269 \\
\hline SEM & 0.306 & 0.303 & 0.422 & 0.896 & 0.481 & 0.220 & 0.780 \\
\hline $\mathrm{CD}$ at $5 \%$ & 0.876 & 0.867 & 1.205 & 2.55 & 1.373 & 0.630 & 2.227 \\
\hline CV \% & 8.061 & 1.630 & 3.831 & 3.23 & 13.07 & 4.718 & 8.852 \\
\hline
\end{tabular}

Table.3

\begin{tabular}{|c|c|c|c|c|c|c|c|}
\hline Hybrids & $\begin{array}{l}\text { Fruit pericarp } \\
\text { thickness }\end{array}$ & $\begin{array}{l}\text { Number of } \\
\text { fruit locules }\end{array}$ & $\begin{array}{l}\text { Fruit volume } \\
\left(\mathrm{cm}^{3}\right)\end{array}$ & $\begin{array}{l}\text { Specific } \\
\text { gravity }\left(\mathrm{g} / \mathrm{cm}^{3}\right)\end{array}$ & $\begin{array}{l}\text { Number of } \\
\text { fruit per plant }\end{array}$ & $\begin{array}{l}\text { Fruit weight } \\
\text { (g) }\end{array}$ & $\begin{array}{l}\text { Fruit Yield } \\
\text { Per Plant (g) }\end{array}$ \\
\hline Gujrat Tomato-3 x Swarn Lalima & 6.81 & 2.65 & 67.25 & 1.10 & 77.25 & 74.04 & 5784.59 \\
\hline Azad T-6 x Punjab Chuhara & 2.72 & 3.00 & 30.31 & 2.69 & 71.25 & 80.71 & 5815.58 \\
\hline CO-3 X Pusa Sadabahar & 3.14 & 2.33 & 36.25 & 2.60 & 66.65 & 93.77 & 6224.77 \\
\hline Azad T-6 X NDT-7 & 5.60 & 4.66 & 52.81 & 1.20 & 62.20 & 106.17 & 6578.77 \\
\hline Utkal Kumari x Utkal Uphar & 5.57 & 6.00 & 44.41 & 1.45 & 74.44 & 64.22 & 4825.53 \\
\hline Pusa Uphar X Utkal Kumari & 3.94 & 6.00 & 73.25 & 0.98 & 73.25 & 71.62 & 5281.16 \\
\hline Marglobe x Palam Pink & 4.09 & 3.00 & 62.52 & 1.51 & 65.45 & 93.82 & 6115.51 \\
\hline Palam Pink x Pusa Sadabahar & 7.61 & 5.66 & 44.42 & 1.78 & 75.62 & 78.54 & 5954.19 \\
\hline Marglobe x Pusa Sadabahar & 4.74 & 4.66 & 73.50 & 1.46 & 64.23 & 106.74 & 6855.91 \\
\hline CO-3 X Utkal Urwasi & 6.04 & 2.25 & 62.50 & 1.40 & 69.25 & 87.18 & 6017.21 \\
\hline Utkal Urwasi x Gujrat Tomato-3 & 5.52 & 2.66 & 51.50 & 1.86 & 73.25 & 94.95 & 6935.08 \\
\hline S-2 X Utkal Uphar & 4.66 & 3.00 & 50.25 & 2.05 & 67.25 & 102.86 & 6897.33 \\
\hline Utkal Urwasi x Palam Pink & 3.93 & 3.33 & 62.65 & 1.71 & 79.82 & 62.50 & 5008.75 \\
\hline Gujrat Tomato-3 x Pusa Sheetal & 4.04 & 4.66 & 67.50 & 1.03 & 76.65 & 69.02 & 5310.38 \\
\hline NDT-7 x S-2 & 4.71 & 3.00 & 85.81 & 1.01 & 64.25 & 86.66 & 5587.90 \\
\hline Punjab Chuhara x Pusa Uphar & 5.33 & 6.00 & 66.50 & 1.24 & 69.25 & 82.21 & 5713.04 \\
\hline Abhilash & 3.59 & 4.66 & 41.50 & 2.44 & 60.80 & 100.18 & 6075.94 \\
\hline Pusa Hybrid-1 & 4.64 & 2.50 & 51.35 & 1.30 & 71.80 & 66.33 & 4787.49 \\
\hline Himshikhar & 5.80 & 2.00 & 60.50 & 1.21 & 64.80 & 72.77 & 4740.49 \\
\hline Himsona & 6.86 & 3.33 & 56.82 & 1.81 & 60.65 & 101.50 & 6130.97 \\
\hline VS- 2853 & 3.87 & 2.23 & 55.86 & 1.30 & 65.25 & 71.97 & 4721.04 \\
\hline Omnia & 7.03 & 5.66 & 106.80 & 0.86 & 59.25 & 106.12 & 5423.00 \\
\hline 'F'test & $* *$ & $*$ & ** & $* *$ & $* *$ & ** & $* *$ \\
\hline GM & 5.006 & 3.77 & 59.075 & 1.582 & 68.666 & 84.481 & 5628.84 \\
\hline SEM & 0.250 & 0.254 & 0.238 & 0.761 & 0.312 & 0.433 & 63.205 \\
\hline $\mathrm{CD}$ at $5 \%$ & 0.714 & 0.725 & 0.681 & 0.217 & 0.889 & 1.237 & 180.38 \\
\hline $\mathrm{CV} \%$ & 8.656 & 11.67 & 0.699 & 8.333 & 0.787 & 0.889 & 1.94 \\
\hline
\end{tabular}




\section{Days to first picking}

Tomato hybrids under this study exhibited significant difference for days to first picking in a range of 43 DAT to 60 DAT (Table 2). Minimum number of days to first picking were observed in Marglobe x Pusa Sadabahar (43.0 DAT) followed by Gujrat Tomato-3 $\mathrm{x}$ Pusa Sheetal (44.0 DAT), Himshikhar (44.0 DAT), Abhilash (44.32 DAT) and VS-2853 (45.33 DAT) which were statistically at par in early picking. The population mean for days to first picking was 47.0 DAT. The less number of days to first flowering and picking indicated earliness of the hybrid. The growing season of tomato in hills starts from MarchApril and ends in July-August, early hybrids or varieties are essentially required for better yield as during rainy season the crop is adversely affected by foliar diseases and low temperature.

Variability in days to first picking has also been observed by Alam et al., (2010) from 89 to 99 DAT and Sharma et al., (2013) from 62 to 82 DAT in tomato hybrids.

\section{Node number of first flowering}

There was significant difference among different hybrids for node number of first flowering. The mean values for node number of first flowering ranged from 4.33 to 11.03 (Table 2). The minimum value for node number of first flowering was observed in Utkal Kumari x Utkal Uphar (4.33) followed by Pusa Uphar x Utkal Kumari (4.90), check Pusa Hybrid-1 (5.00), Gujrat Tomato-3 x Pusa Sheetal (5.20), Abhilash (5.50), Utkal Urwasi x Gujrat Tomto-3 (5.50), Gujrat Tomato-3 x Swara Lalima (5.50) which were statistically at par with each other. The hybrid CO-3 x Pusa Sadabahar exhibited higher value for node number of first flowering (11.03). The population mean was 6.35 . The node number of first flowering is an indicator of earliness of the hybrid. Flower cluster initiation at lower nodes in certain hybrids indicated early bearing habit of those hybrids. Variability for node number of first flowering has also been reported by Chaurasia et al., (2001) from 17.8 to 35.6 in hybrid tomato and Tasisa et al., (2011) 11.70 to 25.00 in open pollinated tomato.

\section{Polar fruit diameter $(\mathrm{cm})$}

Significant difference for fruit length was noted among the hybrids evaluated. The mean value for the fruit length in different hybrids exhibited a range of $3.50 \mathrm{~cm}$ to $11.33 \mathrm{~cm}$. Maximum fruit length was recorded in hybrid NDT-7 $\quad x \quad S-2 \quad(11.33 \quad \mathrm{~cm})$ which was significantly higher than that in other hybrids. The minimum value of fruit length was observed in Gujrat Tomato-3 x Swarna Lalima $(3.50 \mathrm{~cm})$. The population mean for fruit length was found $8.102 \mathrm{~cm}$ (Table 2). Fruit length was mainly due genetic make-up of the hybrids. Variability in fruit length of tomato hybrids has also been reported by Ali et al., (2012) from $5.50 \mathrm{~cm}$ to $7.80 \mathrm{~cm}$, Saleem et al., (2013) from $4.04 \mathrm{~cm}$ to 6.75 $\mathrm{cm}$, Shankar et al., (2013) from $3.00 \mathrm{~cm}$ to $6.10 \mathrm{~cm}$ and Said et al., (2014) from $3.9 \mathrm{~cm}$ to $6.5 \mathrm{~cm}$.

\section{Radial fruit diameter (cm)}

There was a significant variation in fruit diameter across the hybrids (Table 2). Maximum fruit diameter was found in Omnia $(20.86 \mathrm{~cm})$ which was significantly higher than that in all other hybrids tested in present investigation and minimum value was recorded in Gujrat Tomato-3 x Swarna Lalima $(10.50 \mathrm{~cm})$. The population mean for fruit diameter was $15.269 \mathrm{~cm}$. Fruit diameter and fruit length jointly contribute to fruit size which ultimately is related to fruit yield. Existence of variability among the hybrids for fruit size factors (fruit length and diameter) 
may provide opportunity to select a hybrid with desirable fruit size.

\section{Fruit pericarp thickness (mm)}

The perusal of results on pericarp thickness indicated significant variation among the hybrids for this character. The mean value of the fruit pericarp thickness revealed a range of $2.72 \mathrm{~mm}$ to $7.61 \mathrm{~mm}$. The maximum pericarp thickness was recorded in Palam Pink x Pusa Sadabahar $(7.61 \mathrm{~mm})$ which was statistically at par with that in Omnia $(7.03 \mathrm{~mm})$, Himsona $(6.86 \mathrm{~mm})$ and Gujrat Tomato-3 $\mathrm{x}$ Swarna Lalima $(6.81 \mathrm{~mm})$. Whereas, minimum pericarp thickness was observed in Azad T-6 x Punjab Chuhara (2.72 mm) (Table 3). Thick pericarp is a useful character in respect of postharvest handling of fruits during transportation. Since, pericarp cells contain a number of starch grains, therefore the cultivars where accumulation of assimilates in the pericarp was more, the thickness was also high. Almost similar findings on variability in fruit pericarp thickness of tomato hybrids have also been observed by Sekhar et al., (2009) from 5.5 $\mathrm{mm}$ to $7.0 \mathrm{~mm}$, Sharma et al., (2013) from $3.44 \mathrm{~mm}$ to $6.79 \mathrm{~mm}$, Cheema et al., (2013) from $3.5 \mathrm{~mm}$ to $5.5 \mathrm{~mm}$, Shankar et al., (2013) from $3.83 \mathrm{~mm}$ to $6.70 \mathrm{~mm}$ and Singh et al., (2014) from $3.10 \mathrm{~mm}$ to $5.89 \mathrm{~mm}$.

\section{Number of fruit locules}

The analysed data on number of fruit locules presented in (Table 3) indicated that there was significant difference among the hybrids. The population mean was 3.77 . The mean values on number of fruit locules showed a range between 2.00 to 6.00 . The maximum number of fruit locules was observed in hybrids Punjab Chuhara x Pusa Uphar, Pusa Uphar x Utkal Kumari and Utkal Kumari $\mathrm{x}$ Utkal Uphar (6.00) followed by Omnia (5.66) and Palam Pink x Pusa Sadabahar (5.66) which were statistically at par with each other. The minimum number of fruit locules was observed in Himshikhar (2.00). Similar results on variability in number of fruit locules have been obtained by Kurain et al., (2001) from 2.4 to 5.0, Sekhar et al., (2009) from 2.70 to 4.00, Shankar et al., (2013) from 2.33 to 6.50 and Cheema et al., (2013) from 2.00 to 4.50 in hybrid tomatoes. Variability in fruit diameter has also been reported by Singh et al., (2013) from $3.36 \mathrm{~cm}$ to $6.47 \mathrm{~cm}$ polar diameter and $4.47 \mathrm{~cm}$ to $6.65 \mathrm{~cm}$ radial diameter, Singh et al., (2014) from $3.13 \mathrm{~cm}$ to $5.43 \mathrm{~cm}$ and Degade et al., (2015) from 10.58 $\mathrm{cm}$ to $12.42 \mathrm{~cm}$ in tomato hybrids.

\section{Fruit volume $\left(\mathrm{cm}^{3}\right)$}

The analysed data on fruit volume depicted that $\mathrm{F}_{1}$ Omnia registered maximum value of fruit volume $\left(106.80 \mathrm{~cm}^{3}\right)$ which was significantly superior to the rest of hybrids. Minimum value of fruit volume $\left(30.31 \mathrm{~cm}^{3}\right)$ was observed in Azad T-6 x Punjab Chuhara. The grand mean of the population was noted as $59.075 \mathrm{~cm}^{3}$ (Table 3). Corresponding results on variability in fruit volume of tomato hybrids have also been reported by Shibli et al., (1995) from $58.8 \mathrm{~cm}^{3}$ to $257.00 \mathrm{~cm}^{3}$.

\section{Specific gravity of fruits $\left(\mathrm{g} / \mathrm{cm}^{3}\right)$}

Specific gravity of fruits in tomato indicates the quantity of food reserved in the cells and thus, specifies the nutritive value of fruits. There was significant difference in the specific gravity of fruits of different hybrids. The mean values for this character indicated a range of $0.86 \mathrm{~g} / \mathrm{cm}^{3}$ in Omnia to $2.69 \mathrm{~g} / \mathrm{cm}^{3}$ in Azad T-6 x Punjab Chuhara. The maximum value for this trait observed in the hybrid Azad T-6 x Punjab Chuhara $\left(2.69 \mathrm{~g} / \mathrm{cm}^{3}\right)$ was followed by that in CO-3 x Pusa Sadabahar $\left(2.60 \mathrm{~g} / \mathrm{cm}^{3}\right)$, Abhilash $\left(2.44 \mathrm{~g} / \mathrm{cm}^{3}\right)$ and $\mathrm{S}-2 \mathrm{x}$ Utkal Uphar $\left(2.05 \mathrm{~g} / \mathrm{cm}^{3}\right)$. The minimum specific gravity of fruits was observed in 
Omnia $\left(0.86 \mathrm{~g} / \mathrm{cm}^{3}\right)$. The population mean for this trait was $1.58 \mathrm{~g} / \mathrm{cm}^{3}$ ) (Table 3). A corresponding range of variability in specific gravity of fruits have also been realized by Shibli et al., (1995) from $0.95 \mathrm{~g} / \mathrm{cm}^{3}$ to 1.95 $\mathrm{g} / \mathrm{cm}^{3}$ in tomato hybrids

\section{Number of fruits per plant}

The difference among the hybrids with respect to number of fruits per plant was highly significant which varied from 59.25 to 79.82. Maximum number of fruits per plant was observed in Utkal Urwasi x Palam Pink (79.82) which was significantly higher than that in all the other hybrids tested in present investigation. The other hybrids with comparatively higher number of fruits per plant were Gujrat Tomato -3 x Swarna Lalima (77.25), Gujrat Tomato-3 x Pusa Sheetal (76.65), Palam Pink $x$ Pusa Sadabahar (75.62), Utkal Kumari x Utkal Uphar (74.44), Pusa Uphar x Utkal Kumari and Utkal Urwasi $x$ Gujrat Tomato-3 (73.25). Minimum number of fruits per plant was found in the Omnia (59.25). The population mean for this trait was 68.66 (Table 3). In this investigation variation in the number of fruit per plant was due to the genetic make-up of the hybrids as all the hybrids tested were given almost similar type of cultural atmospheric and edaphic environments. The results of present study were in accordance with those reported by Sekhar et al., (2009) who noted variability in number of fruits per plant from 27.00 to 73.53, Singh et al., (2013) from 20.89 to 22.50, Saleem et al., (2013) from 48 to 95 and Cheema et al., (2013) from 7.50 to 32.00 in tomato hybrids and/or genotypes.

\section{Fruit weight (g)}

There was a highly significant difference among 22 hybrids with respect to fruit weight (Table 3). The fruit weight ranged between $62.50 \mathrm{~g}$ to $106.74 \mathrm{~g}$. Maximum fruit weight was registered in Marglobe x Pusa Sadabahar $(106.74 \mathrm{~g})$ followed by at par value in Azad T-6 x NDT-7 (106.17 g). The other hybrids with higher fruit weight were S-2 x Utkal Uphar (102.86 g), Himsona (101.50 g) and Abhilash (100.18 g). Minimum value for fruit weight was observed in Utkal Urwasi x Palam Pink $(62.50 \mathrm{~g})$. The population mean was 84.48. Generally, fruit weight is inversely associated with number of fruits per plant although both of these traits are principal yield attributing traits. The fruit weight which is a function of fruit size (fruit length and diameter) may be subject of consumer's or market choice but fruit number is independent of the purpose of end use. Therefore, preference should be given to the hybrids with higher number of fruits per plant rather than those having big and bulking fruits. Corresponding to above results variability in average fruit weight and inverse association with number of fruits per plant have also been reported by Sekhar et al., (2009) from $38.86 \mathrm{~g}$ to $67.14 \mathrm{~g}$, Sharma et al., (2013) from $30.77 \mathrm{~g}$ to $77.80 \mathrm{~g}$, Singh et al., (2013) from $65.00 \mathrm{~g}$ to $72.27 \mathrm{~g}$, Cheema et al., (2013) from 30.00 $\mathrm{g}$ to $52.50 \mathrm{~g}$, and Degade et al., (2015) from $16.80 \mathrm{~g}$ to $24.69 \mathrm{~g}$ in tomato hybrids. Said $e t$ al., (2014) from $23.0 \mathrm{~g}$ to $69.8 \mathrm{~g}$ in open pollinated tomato.

\section{Fruit yield per plant (g)}

The fruit yield is supposed to be the ultimate economic trait in tomato as well as other fruit vegetables. Fruit yield per plant is an accurate assessment of potentiality of a particular hybrid at individual plant level. The data on fruit yield per plant exhibited a wide variability among the hybrids evaluated. Highest fruit yield per plant was observed in Utkal Urwasi x Gujrat Tomato-3 (6935.08 g) followed by statistically at par values in S-2 x Utkal Uphar (6897.33 g) and Marglobe $\mathrm{x}$ Pusa Sadabahar (6830.91 g). The $\mathrm{F}_{1} \mathrm{~S}$ VS2853, Himshikhar and check Pusa Hybrid-1 
exhibited comparatively lower fruit yield per plant i.e. $4721.04 \mathrm{~g}, 4740.49 \mathrm{~g}$ and $4787.49 \mathrm{~g}$, respectively. The mean of population for this trait was $5628.84 \mathrm{~g}$ (Table 3). The results indicated that certain hybrids developed from crosses between commercial grown openpollinated varieties were more heterotic as compared to commercial $\mathrm{F}_{1}$ hybrids developed by different organizations. The cumulative results of fruit weight, number of fruit per plant and fruit yield per plant proved that the hybrids exhibiting maximum number of fruits per plant (Utkal Urwasi x Palam Pink) or maximum fruit weight (Azad T-6 x NDT-7) did not have maximum fruit yield per plant. This was because of the fact that the hybrid with highest number of fruit per plant had lower fruit weight and vice versa. The hybrid having highest fruit yield per plant i.e. Utkal Urwasi x Gujrat Tomato-3 (6935.08 g) had comparatively higher number of fruits per plant (73.25) as well as heavier fruits (94.95 g). Variability in fruit yield per plant in tomato hybrids have also been reported by Sharma et al., (2013) from $681.00 \mathrm{~g}$ to $1278.19 \mathrm{~g}$, Singh et al., (2013) from 1000.36 $\mathrm{g}$ to $1000.63 \mathrm{~g}$, Saleem et al., (2013) from $1000.93 \mathrm{~g}$ to $3000.72 \mathrm{~g}$, Shankar et al., (2013) from $1000 \mathrm{~g}$ to $3000.90 \mathrm{~g}$.

\section{References}

Ahmad, S.D., and Fehmida, A. 2007. Morphogenic comparisons of three tomato cultivars from Azad Jammu and Kashmir, Pakistan. Sarhad J. Agric., 23:2-4.

Alam, M.S., Sultana, N., Ahmed, S., Hossain, M.M. and Islam, A.K.M.A. 2010. Performance of heat tolerant tomato hybrid lines under hot, humid condition. Bangladesh J. Agril. Res., 35(3): 367373.

Ali, W., Jilani, M.S., Naeem, N., Waseem, K., Khan, J., Ahmad, M.J. and Arullah, G. 2012. Evaluation of different hybrids of tomato under the climatic conditions of Peshawar, Sarhad J. Agric., 28(2): 200211.

Anonymous, 2015. Area and production of vegetable production in India. www.nhb.org.

Babu, M.A., Singh, D. and Gothandam, K.M. 2012. The effect of salinity on growth, hormone and mineral element in leaf and fruit of tomato cultivar PKM1. J. Animal Plant Sci., 22 (1): 159-164.

Chaurasia, S.N.S., Nirmal, D. and Singh, K.P. 2001. Influence of graded doses of nitrogen of indeterminate tomato hybrids, Veg. Sci., 28(2): 157-159.

Cheema, D.S., Singh, N. and Jindal, S.K. 2013. Evaluation of indeterminate tomato hybrids for fruit yield and quality traits under net house and open field condition, Veg. sci., 40(1): 45-49.

Degade, S.B., Borad, A.V. and Dhaduk, L.K. 2015. Studies on hybrid vigour in $F_{1}$ and its retention in $\mathrm{F}_{2}$ for fruit firmness and related traits in tomato, Inter. J. Applied Bio. \& Phar. Tech., 6(1): 193-198.

Falconer, D.S., Mackay, T. F. C. Introduction to Quantitative Genetics. 4th ed. London, UK: Benjamin Cummings. 1996, 122-125.

Kalloo, G., 1991. Introduction. In: Kalloo G. (ed.) Genetic improvement of tomato, monographs on theoretical and applied genetics. Springer-Verlag, Berlin, pp.19.

Kurain, A., Peter, K.V. and Rajan, S. 2001. Heterosis for yield components and fruit characters in tomato. J. Tropical Agric., 39: $5-8$

Larry, R., and Joanne, L. 2007. Genetic improvement of solanaceous crop. Enfield Sci. pub., 2p.

Momotaj, A., Scott, J.W. and Schuster, D.J. 2005. Searching for silverfly whitefly and begomovirus resistance genes from Lycopersicon hirsutum accession LA1777. Acta. Hort., 695: 417-422 
Muigai, S.G., Schuster, D.J., Snyder, J.C., Scott, J.W., Bassett, M.J. and Mcauslane, H.J. 2002. Mechanism of resistant in Lycopersicon germplasm to Bemisia argentifolii. Phyoparasitica, 347-360.

Rajdan, M.K., and Mattoo, A.K. 2006. Genetic improvement of solanaceous crop Sci. pub., 75.

Rick, C.M., 1998. Tomato-like nightshades, affinities and auto-ecology and breeder opportunities. Economic Botany, 42:145-154.

Said, F.A., Farsi, K.A., Khan, I.A., Ali, A., Khan, M.M. and Iqbal, Q. 2014. Evaluation of adaptability and nutritional quality of 54 tomato accession grown in Oman. J. Food Agric. \& Environ, 12(2): 40-50.

Saleem, M.Y., Iqbal, Q. and Asghar, M. 2013. Genetic variability, heritability character association and path analysis in $\mathrm{F}_{1}$ hybrids of tomato. Pak. J. Agri. Sci., 50(4): 649-653.

Sekhar, L., Prakesh, B.G., Salimath, P.M., Sridevi, O. and Patil, A.A. 2009. Performance of productive single cross hybrids in tomato (Solanum lycopersicon L.). Karnataka J. Agric. Sci., 22(4): 877-878.

Shankar, A., Reddy, R.V.S.K., Sujata, M. and Pratap, M. 2013. Genetic variability studies in $\mathrm{F}_{1}$ generation of tomato (Solanum lycopersicon L.) JOSR J. Agric. Vet. Sci. 4(5): 31-34.
Production and evaluation of tomato hybrids using diallele genetic design. Indian J. Hort., 70: 4-6.

Shibli, R.A., Ereifej, K.I., Ajlouni, M.A. and Hussain, A. 1995. Evaluation of thirteen open pollinated cultivars and three hybrids of tomato (Lycopersicon esculentum Mill.) for physical properties and chemical composition of fruits. Pak. J. Agri. Sci., 32: 2-3.

Sindhu, A.S., Kalloo, and Pandita, M. 1980. Studies on some important aspects of floral biology in vegetable crops. Haryana J. Hort. Sci., 9: 20-21.

Singh, A., Ahirwar, C.S. and Prasad, V.M. 2013. Evaluation of tomato hybrids (Lycopersicon esculentum Mill) in Allahabad agro climatic conditions. Trends in Bioscience, 6(6): 744-746.

Singh, T., Singh, N., Bahuguna, A., Nautiyal, M. and Sharma, V.K. 2014. Performance of tomato (Solanum lycopersicon L.) hybrids for growth, yield and quality inside polyhouse under Mid Hill Condition of Uttarakhand, Am. J. Drug Discov. Dev., $68: 1-8$.

Tassia, J., Belew, D., Bantte, K. and Gebreselassie, W. 2011. Variability, heritability and genetic advance in tomato (Lycopersicon esculentum Mill) genotypes in West Shoa, Ethiopia. American-Eurasian J. Agric. \& Environ. Sci., 11(1): 87-94.

Sharma, D., and Sharma, H.R. 2013.

\section{How to cite this article:}

Shivani Dhyani, A.C. Misra, Vivek Panday and Paramjeet sajwan. 2017. Evaluation of Tomato (Solanum lycopersicon L.) Hybrids for Fruit Yield Characters in Hill Region of Uttarakhand. Int.J.Curr.Microbiol.App.Sci. 6(9): 1622-1633. doi: https://doi.org/10.20546/ijcmas.2017.609.200 